\title{
INTEGRASI KETERAMPILAN ABAD 21 DALAM PENGEMBANGAN PERANGKAT PEMBELAJARAN PADA KONSEP COMMUNITY OF INQUIRY
}

\author{
Anjas Rusdiyanto Soleh ${ }^{1}$, Zainal Arifin ${ }^{1}$ \\ ${ }^{1}$ Universitas Muhammadiyah Surakarta, Indonesia \\ *Corresponding Address: a310180016@student.ums.ac.id
}

Naskah diterima: 8 Agustus 2021| Disetujui: 2 September 2021 | Diterbitkan: 3 September 2021

\begin{abstract}
This research aim to identify integration of $21^{\text {st }}$ century skills in the development of learning tools.. This research uses qualitative research by applying descriptive methods. The source data in this study is a learning device that has been developed in the PPL Program of FKIP UMS with the pattern of the Prospective Teacher Motivator Program based on the concept of CoI. The data is the form of parts in learning tools which are the integration of $21^{\text {st }}$ century competency skills which consist of 4Cs. Data collection techniques in this study are note-taking and documentation techniques. Data were analyzed using content analysis techniques. The results of this study indicate that the integration of $21^{\text {st }}$ century skills in the development of learning tools in the CoI concept includes four overall aspects, namely critical thinking, creativity, communication, and collaboration or 4C, found in the Lesson Plan, Student Worksheet, and evaluation instrument. Its relevance to the CoI concept that critical thinking integrated in the cognitive presence aspect, creativity integrated in the social presence aspect, and communication and collaboration in the teaching presence aspect.
\end{abstract}

Keywords: $21^{\text {st }}$ century skills; learning tools; community of inquiry; lesson plan

Abstrak: Tujuan penelitian ini untuk mengidentifikasi wujud integrasi kecakapan abad 21 dalam pengembangan perangkat pembelajaran pada konsep Community of Inquiry. Penelitian ini menggunakan jenis penelitian kualitatif dengan menerapkan metode deskriptif. Sumber data dalam penelitian ini yaitu perangkat pembelajaran yang telah dikembangkan pada kegiatan Program Pengenalan Lapangan FKIP UMS dengan pola Program Calon Guru Penggerak (PCGP) berdasarkan konsep Community of Inquiry. Data berupa bagian-bagian dalam perangkat pembelajaran yang merupakan integrasi dari kompetensi kecakapan abad 21 yang terdiri dari 4C. Teknik pengumpulan data dalam penelitian ini menggunakan teknik catat dan dokumentasi. Data dianalisis dengan menggunakan teknik analisis konten (content analysis). Hasil penelitian ini menunjukkan bahwa integrasi kecakapan abad 21 dalam pengembangan perangkat pembelajaran dalam konsep Community of Inquiry, mencakup empat aspek secara keseluruhan yaitu critical thinking, creativity, communication, dan collaboration atau 4C yang ditemukan pada Rencana Pelaksanaan Pembelajaran (RPP), Lembar Kerja Peserta Didik (LKPD), dan instrumen evaluasi. Relevansinya dengan konsep CoI, aspek berpikir kritis terintegrasi dalam aspek kehadiran kognitif (cognitive presence), kreativitas terintegrasi dalam aspek kehadiran sosial (social presence), dan komunikasi serta kolaborasi terintegrasi dalam aspek kehadiran pengajaran (teaching presence).

Kata kunci: kecakapan abad 21; perangkat pembelajaran; community of inquiry; rencana pelaksanaan pembelajaran 


\section{PENDAHULUAN}

Pembelajaran merupakan suatu bantuan kaitannya dengan suatu hal yang diberikan oleh pendidik dengan tujuan agar terjadi suatu proses pemahaman mengenai ilmu pengetahuan yang termasuk dalam aspek kognitif, penguasaan mengenai suatu kemahiran serta sikap maupun kepercayaan yang terbentuk dalam diri peserta didik yang termasuk dalam aspek afektif, dan dikuasainya suatu keterampilan tertentu (aspek psikomotor) (Marsudi et al., 2019). Apabila mengacu pada definisi tersebut, pembelajaran terdapat tiga komponen di dalamnya, yang pertama yaitu aspek kognitif atau aspek yang berhubungan dengan pengetahuan atau tingkat kognitif peserta didik, yang kedua berupa aspek afektif atau aspek yang berhubungan dengan sikap peserta didik dalam pembelajaran, dan yang ketiga berhubungan dengan aspek psikomotor yang berkaitan dengan keterampilan peserta didik dalam proses pembelajaran. Adanya keterkaitan antara ketiga aspek tersebut dalam proses pembelajaran tentunya didukung dengan komponen-komponen penunjang yang lain dalam proses pembelajaran tersebut.

Selain pendidik dan peserta didik sebagai objek utama di dalamnya, terdapat komponen lain dalam terlaksananya suatu proses pembelajaran, yaitu tujuan. Tujuan pembelajaran yang telah direncanakan atau dicanangkan oleh guru agar peserta didik mampu memahami atau berhasil dalam proses pembelajaran yang dilakukannya. Terwujudnya tujuan yang direncanakan oleh guru dalam proses pembelajaran tersebut tidak bisa dilepaskan atau dipisahkan dari perangkat pembelajaran yang telah dibuat oleh guru sebelum proses belajar mengajar. Perangkat pembelajaran sebagai seperangkat alat yang berperan dalam menunjang proses pembelajaran terdiri dari beberap poin. Perangkat pembelajaran tersebut terdiri dari Rencana Pelaksanaan Pembelajaran (RPP), materi atau bahan ajar, Lembar Kerja Peserta Didik (LKPD), dan instrumen evaluasi atau penilaian.

Reiser dan Dempse menyatakan bahwa perencanaan pembelajaran merupakan suatu tata urutan yang sistematis yang di dalamnya menjelaskan mengenai kegiatan yang akan dilaksanakan kaitannya dengan pendidikan yang bertujuan untuk meningkatkan proses pembelajaran secara substansial (Anggraeni \& Akbar, 2018). Perencanaan pembelajaran yang disusun oleh guru sebelum mengajar tersebut tentunya harus diseuaikan dengan karakteristik peserta didik dalam kondisi lingkungan sekitar, dengan kata lain bahwa dalam pengembangan atau penyusunan rencana pelaksanaan pembelajaran tersebut tetap mengacu pada kebutuhan yang diperlukan dan juga untuk mencapai tuntutan yang terdapat dalam kurikulum.

Jenis perangkat pembelajaran yang kedua yaitu berkaitan dengan materi ajar. Materi ajar dalam sebuah perangkat pembelajaran disebut juga sebagai bahan ajar menjadi komponen yang penting dalam pembelajaran (Soleh et al., 2021). Dalam sebuah bahan ajar tersaji mengenai berbagai materi 
yang akan dijelaskan oleh guru sebagai pendidik kepada peserta didik dalam proses belajar mengajar. Dalam materi ajar tersebut menyajikan berbagai bahasan yang menjadi dasar bagi guru untuk mentransfer ilmu atau materi kepada peserta didik. Bahan ajar dalam hal ini menjadi bahan atau modal utama bagi guru dalam melakukan proses pembelajaran.

Perangkat pembelajaran selanjutnya berupa Lembar Kerja Peserta Didik (LKPD). Lembar Kerja Peserta Didik dapat didefinisikan sebagai satu jenis perangkat pembelajaran yang dimanfaatkan oleh guru dalam mengukur seberapa jauh pemahaman peserta didik terhadap materi yang telah dijelaskan oleh guru dan juga berfungsi untuk meningkatkan taraf pemahaman peserta didik mengenai materi yang telah dijelaskan oleh guru dalam proses belajar mengajar (Hamidah et al., 2018). Jenis perangkat pembelajaran selanjutnya yaitu mengenai instumen evaluasi atau penilaian. Aspek tersebut termasuk dalam jenis perangkat pembelajaran yang memiliki fungsi atau tujuan yaitu sebagai sebuah instrumen atau alat untuk mengukur tingkat pemahaman dari masing-masing peserta didik kaitannya dengan materi pembelajaran yang sudah dalam proses belajar mengajar. Pada umumnya, bentuk perangkat pembelajaran ini berupa kriteria atau poin-poin yang menjelaskan capaian yang harus dilakukan oleh peserta didik dengan tujuan untuk mengevaluasi tingkat pemahaman peserta didik dan juga untuk mengukur keterampilan peserta didik mengenai materi yang disampaikan dalam pembelajaran.

Penyusunan perangkat pembelajaran tersebut disesuaikan dengan keadaan atau kondisi yang sesuai dengan zamannya. Pada era abad 21, guru dituntut untuk memahami kompetensi kecakapan abad 21 yang menjadi dasar bahwa sebagai seorang guru sudah semestinya memahami kompetensi tersebut. Kompetensi atau pemahaman yang sesuai dengan abad 21 yaitu mengenai kecakapan seorang guru dalam pengembangan pedagogik. Pengembangan pedagogik berkaitan dengan tingkat kemampuan seorang guru kaitannya dalam perancangan serta pengembangan pembelajaran dengan baik. Untuk dapat mengembangkan sebuah pembelajaran dengan baik, tentunya hal tersebut tidak lepas dari perangkat pembelajaran yang disusun oleh guru.

Penyusunan perangkat pembelajaran tersebut tentunya sangat menentukan keberhasilan dalam proses pembelajaran yang dilakukan (Zendrato, 2016). Wardani menjelaskan mengenai apa saja faktor yang menjadi bahan pertimbangan bagi guru sebagai pendidik dalam merencanakan pembelajaran, faktor tersebut antara lain 1) peserta didik, yang berkaitan dengan kemampuan, minat, jumlah peserta didik, dsb, 2) materi pelajaran atau bahan ajar, 3) pendidik atau guru yang berkaitan dengan pemahaman esensi atau hakikat pendidikan, kemampuan dalam memanajemen pembelajaran, kemampuan dalam mengimplementasikan suatu pendekatan dalam pembelajaran, dsb, dan 4) 
berkaitan dengan sarana yang memadai dalam pembelajaran yang meliputi ruangan, fasilitas, dan waktu yang tersedia (Zendrato, 2016).

Penyusunan perangkat pembelajaran tersebut pada dasarnya disesuaikan terhadap tuntutan peraturan atau kurikulum yang diterapkan pada satuan pendidikan. Pada saat sekarang ini, kurikulum yang diberlakukan pada setiap satuan pendidikan yaitu kurikulum 2013. Penerapan kurikulum 2013 tersebut telah menjurus pada proses pembelajaran yang mengarah dengan kompetensi kecakapan abad 21 (Fitri et al., 2020). Tujuan dari diterapkannya pembelajaran abad 21 pada kurikulum 2013 tersebut tentunya berkaitan dengan revolusi Industri 4.0 yang mengakibatkan semakin ketatnya persaingan antarindividu kaitannya dengan pengembangan dalam aspek keterampilan dan juga potensi yang ada dalam diri mereka yang sudah semestinya memiliki keterampilan 4C (Kurniawan, 2020). Selain itu, kaitannya dengan peran aktif seseorang pada era globalisasi pada abad 21 ini, maka setiap warga negara memiliki kewajiban untuk memiliki kemampuan yang dapat dijadikan dasar dalam menjawab tututan zaman (Septikasari \& Frasandy, 2018).

National Education Association menjelaskan mengenai kompetensi kecakapan abad 21 dengan mengenalkan istilah 4C. keterampilan atau kecakapan 4C tersebut yaitu terdiri dari kemampuan berpikir kritis (Critical Thinking), kemampuan berkreativitas (Creativity), kemampuan berkomunikasi (Communication), dan kemampuan dalam berkolaborasi (Collaboration)(Susanti \& Arista, 2019).

Kemampuan berpikir kritis (Critical Thinking) merupakan merupakan perilaku belajar yang berhubungan dengan pemecahan masalah. Indikator dalam kemampuan berpikir kritis ini adalah 1) apabila seseorang mampu mengenali masalah yang sedang dihadapinya dalam kehidupan, 2) mampu menggali berbagai macam informasi, 3) mampu memecahkan masalah dengan menghasilkan sebuah solusi dari permasalahan yang dihadapi, 4) mampu menilai suatu realitas yang ada, serta 5) memiliki kemampuan dalam menyimpulkan sesuatu (Putri et al., 2019). Selain itu, terdapat indikator lain yang menjadi dasar dalam kemampuan berpikir kritis dalam proses pembelajaran, yaitu 1) mampu menyampaikan penjelasan secara sederhana, 2) mampu membangun keterampilan dasar peserta didik, 3) memeiliki kemampuan untuk menyusun sebuah simpulan, 4) memiliki kemampuan dalam melakukan penjelasan mengenai suatu hal, dan 5) mampu memanajemen strategi atau taktik mengenai sebuah hal (Yusliani et al., 2019). Sejalan dengan hal tersebut, keterampilan berpikir kritis memiliki keterkaitan dengan kemampuan dalam mengidentifikasi, menganalisis, dan memecahkan suatu permasalahan dengan yang dilaksanakan dengan prinsip kreatif serta berpikiran yang logis sehingga mampu memperoleh pertimbangan dan keputusan yang tepat (Sholikha \& Fitrayati, 2021). 
Kreativitas dapat didefinisikan sebagai kemampuan yang berfungsi kaitannya dengan pemenuhan atau penciptaan suatu hal baru. Kreativitas mampu menajdi modal bagi peserta didik dalam mewujudkan daya saing dan memberikan kontribusi terhadap berbagai peluang bagi dirinya sendiri yang bermanfaat dalam pemenuham kebutuhannya sendiri (Sugiyarti et al., 2018). Kaitannya dengan aspek kreativitas dalam kompetensi kecakapan abad 21 tersebut, Rubrics \& Resources menyebutkan bahwa salah satu indikator yang menjadi dasar dalam aspek kreativitas ini yaitu berkaitan dengan adanya suatu ide yang kemudian diolah sehingga menghasilkan sebuah produk dari ide tersebut. (Nurhaifa et al., 2020).

Komunikasi merupakan kemampuan seseorang kaitannya terhadap proses interaksi dengan orang lain. Komunikasi juga dapat dimaknai ketika dalam pembelajaran terwujudnya komunikasi yang tidak hanya satu arah melainkan adanya interaksi yang intensif antara antara guru dan peserta didik, peserta didik dan guru, dan antar peserta didik sehingga memunculkan timbal balik yang efektif dalam pembelajaran (Rafi et al., 2016). Kemampuan berkomunikasi bagi peserta didik sebagai pembelajar abad 21 tersebut memiliki kemampuan untuk menyampaikan suatu informasi kepada orang lain serta memiliki kemampuan dalam mengungkapkan argumentasi atau pendapat dirinya sendiri kepada orang lain.

Kolaborasi yaitu satau aspek kemampuan dalam kompetensi kecakapan abad 21 yang harus dikuasai oleh peserta didik dengan tujuan sebagai dasar dalam menjalin kerjasama dengan orang lain. Indikator keterampilan berkolaborasi ini antara lain saling ketergantungan positif, mampu berinteraksi satu sama lain mengenai suatu hal, memiliki sikap tanggungjawab, serta memiliki keterampilan dalam berkomunikasi dan bekerja sama dalam sebuah kelompok (Putri et al., 2019).

Berdasarkan empat aspek dalam kompetensi kecakapan abad 21 tersebut menjadi dasar untuk guru dalam mengembangkan seperangkat pembelajaran yang digunakannya untuk kebutuhan mengajar. Pengembangan perangkat pembelajaran dengan mengintegrasikan keterampilan abad 21 yang selaras dengan tuntutan kurikulum 2013 tentu sudah harus dilaksanakan oleh guru dalam menyusun perangkat pembelajaran sedini mungkin. Salah satu pendekatan atau kerangka pembelajaran yang dikaji dalam penelitian ini yaitu Community of Inquiry atau CoI. Garrison \& Vaughan menyatakan bahwa Community of Inquiry merupakan satu diantara berbagai konsep dalam pembelajaran yang memposisikan peserta didik untuk membentuk suatu perkumpulan atau komunitas yang sifatnya dinamis dengan masing-masing peserta didik bertanggung jawab mengolah makna dan mengkonfirmasi pemahaman yang dilakukan dengan keikutsertaan atau partisipasi secara aktif dalam proses inkuiri (Kirana et al., 2021). Konsep Community of Inquiry apabila diintegrasikan dalam pengembangan perangkat pembelajaran tentunya memuat aspek-aspek yang terdapat pada konsep 
Community of Inquiry tersebut. Aspek-aspek tersebut yaitu social presence (kehadiran sosial), cognitive presence (kehadiran kognitif), dan teaching presence (kehadiran pengajaran). Ketiga aspek tersebut menjadi satu kesatuan dalam sebuah pembelajaran yang memungkinkan adanya keterkaitan antara aspek satu dengan aspek yang lainnya. Selaras dengan hal tersebut, konsep Community of Inquiry dalam pembelajaran sebagai suatu pendekatan yang menekankan proses pembelajaran pada tiga aspek, yaitu social presence, cognitive presence, dan teaching presence (Henri dalam Setiaji et al., 2015). Ketiga aspek tersebut menjadi satu kesatuan dalam proses pembelajaran sehingga tercipta suatu iklim belajar yang maksimal.

Konsep Community of Inquiry dalam penelitian ini dihubungkan dengan kompetensi kecakapan abad 21 yang sudah semestinya dipahami oleh guru dan peserta didik sebagai penunjang dalam proses pembelajaran. Relevansi dari hal tersebut didasarkan pada pengembangan perangkat pembelajaran yang digunakan dalam kegiatan mengajar. Aspek-aspek yang terdapat dalam kecakapan abad ke-21 yang terdiri dari 4C, yaitu Critical Thinking (kemampuan berpikir atau bernalar kritis), Creativity (kemampuan berkreativitas), Communication (kemampuan berkomunikasi), dan Collaboration (kemampuan berkolaborasi) akan dipadankan atau dihubungkan dengan aspek yang terdapat dalam konsep Community of Inquiry yang terdiri dari aspek kehadiran sosial, kehadiran kognitif, dan kehadiran pengajaran (social presence, cognitive presence, dan teaching presence).

Aspek social presence merupakan aspek dalam konsep Community of Inquiry yang mendasarkan pada kegiatan yang bertujuan terbangunnya komunikasi yang efektif serta pengembangan ikatan yang bersifat sosial yang merupakan salah satu hal penting dimana kelompok mampu berkolaborasi secara terbuka dan mampu menggabungkan tujuan secara bersama dalam sebuah kelompok. Dalam aspek social presence ini, kaitannya dengan proses pembelajaran, kegiatan yang dilakukan berdasarkan aspek social presence ini antara lain berinteraksi secara efektif antar peserta didik dan pendidik, ekspresi yang menyenangkan dalam kegiatan pembelajaran, serta adanya kolaborasi antara peserat didik dan pendidik dalam proses pembelajaran.

Aspek cognitive presence yaitu pengembangan serta konfirmasi mengenai pemahaman yang dapat dilakukan melalui kegiatan kolaborasi dan juga refleksi. Dalam aspek cognitive presence ini, kaitannya dengan proses pembelajaran, kegiatan yang dilakukan berdasarkan aspek cognitive presence ini antara lain bertukar informasi antara peserta didik dan guru, mengaplikasikan ide-ide baru yang ditemukan pada saat pembelajaran, serta mengoneksikan atau menghubungkan atau mengkorelasikan antar ide tersebut. Indikator yang terdapat dalam aspek kehadiran kognitif (cognitive presence) pada konsep CoI dalam pembelajaran, bahwa indikator dalam aspek kognitif 
dapat diintegrasikan dalam kegiatan bertanya (tanya jawab), melatih daya pikir, dan mengembangkan keterampilan (Setiawan \& Komalasari, 2020).

Aspek teaching presence yaitu aspek yang berkaitan dengan pengajaran yang dilakukan oleh guru ketika proses pembelajaran. Aspek teaching presence ini memiliki beberapa indikator yang menunjang, antara lain 1) berbagi pengalaman antara peserta didik dan pendidik, 2) penekanan pada proses diskusi dalam pembelajaran sehingga terjadi interaksi yang aktif, serta 3) penjelasan materi yang dilakukan oleh guru. Penjelasan materi tersebut tentunya sangat berhubungan dengan aspek teaching presence karena aspek ini menekankan pada kemampuan seorang guru dalam proses pengajaran yang menjadikan poin penting terlaksananya pembelajaran tersebut.

Penelitian mengenai integrasi kecakapan abad 21 ini telah dilaksanakan oleh beberapa peneliti sebelumnya yaitu Simanjuntak meneliti mengenai desain pembelajaran yang dihuungkan dengan basis proyek terhadap 4C. Hasil dari penelitian Simanjuntak yaitu terciptanya desain pembelajaran fisika berbasis proyek yang didalamnya diharapkan mampu mengembangkan kompetensi 4C peserta didik (Simanjuntak et al., 2019). Partono meneliti tentang berbagai strategi dalam peningkatan kompetensi kecakapan abad 21. Hasil penelitian dari Partono yaitu mengenai penguatan kompetensi 4C di SIDH (Sekolah Indonesia Den Haag sebagai objek penelitian) yang telah menerapkan kompetensi $4 \mathrm{C}$ dalam setiap pembelajaran dengan tujuan pentingnya kompetensi tersebut untuk masa depan (Partono et al., 2021).

Letasado yang meneliti mengenai engaruh yang timbul dari proses pengimplementasian pembelajaran dengan menggunakan pendekatan saintifik yang dengan dasar keterampilan belajar serta inovasi 4C yang dihubungkan dengan rasa percaya diri serta kemampuan dalam membaca suatu pemahaman. Hasil penelitian dari Letasado menunjukkan bahwa terdapat pengaruh antara penerapan pembelajaran dalam pendekatan saintifik dengan dasar berupa keterampilan belajar dan inovasi 4C kaitannya dengan rasa percaya diri peserta didik dan kemampuan dalam membaca suatu pemahaman (Letasado \& Muhsam, 2020).

Berdasarkan beberapa hasil penelitian tersebut, belum ditemukan penelitian mengenai keterampilan atau kecakapan abad 21 yang diintegrasikan dalam pengembangan perangkat pembelajaran pada konsep Community of Inquiry (CoI). Oleh karena itu, penelitian ini bertolak dari adanya tuntutan keterampilan abad 21 dalam pembelajaran pada kurikulum 2013 ini serta akan dikorelasikan wujud pengintegrasian keterampilan abad 21 dalam pengembangan perangkat pembelajaran tersebut dengan konsep Community of Inquiry (CoI) yang terdiri dari 3 aspek, yaitu social presence (kehadiran sosial), cognitive presence (kehadiran kognitif), dan teaching presence (kehadiran pengajaran). Berdasarkan hal tersebut, penelitian ini bertujuan untuk medeskripsikan 
wujud atau bentuk integrasi kecakapan abad 21 dalam pengembangan perangkat pembelajaran pada konsep Community of Inquiry yang merupakan perangkat pembelajaran yang telah dikembangkan pada praktik pembelajaran dalam kegiatan Pengenalan Lingkungan Persekolahan (PLP) 2 yang diadakan oleh FKIP Universitas Muhammadiyah Surakarta.

\section{METODE}

Jenis penelitian yang diterapkan dalam penelitian ini yaitu penelitian kualitatif dengan menerapkan metode deskriptif. Jenis penelitian deskriptif dapat diartikan sebagai sebuah proses dalam memecahkan masalah yang dilakukan dengan penyelidikan dengan cara menggambarkan atau menuliskan keadaan subjek maupun objek-objek dalam penelitian (Sugiyono, 2015). Sumber data dalam penelitian ini yaitu perangkat pembelajaran yang telah dikembangkan pada kegiatan Program Pengenalan Lapangan FKIP UMS dengan pola Program Calon Guru Penggerak (PCGP) yang berdasarkan konsep Community of Inquiry. Data dalam penelitian ini berupa bagian-bagian dalam perangkat pembelajaran yang merupakan integrasi dari kecakapan abad 21 yang tercakup dalam kompetensi 4C. Teknik pengumpulan data dalam penelitian ini menerapkan teknik catat serta dokumentasi. Peneliti mencatat setiap data pada perangkat pembelajaran yang merupakan perangkat yang telah dikembangkan pada kegiatan Pengenalan Lingkungan Persekolahan (PLP) 2 FKIP UMS. Setelah peneliti mencatat temuan data pada perangkat pembelajaran tersebut, kemudian peneliti mengklasifikasikannya ke dalam masing-masing aspek dalam kecakapan abada 21 dilanjutkan dengan mendokumentasikannya. Teknik analisis data dalam penelitian ini menerapkan teknik analisis isi. Teknik tersebut diterapkan dengan menganalisis perangkat pembelajaran yang telah dikembangkan dalam kegiatan PLP 2 FKIP UMS dengan topik yang dianalisis berupa kompetensi kecakapan abad 21 yang terdiri dari kemampuan berpikir kritis (Critical Thinking), kemampuan berkreativitas (Creativity), kemampuan berkomunikasi (Communication), dan kemampuan dalam berkolaborasi (Collaboration) yang terdapat pada perangkat pembelajaran tersebut, kemudian dikorelasikan dengan konsep Community of Inquiry (CoI) yang terdiri dari tiga aspek, yaitu aspek kehadiran sosial (social presence), kehadiran kognitif (cognitive presence), dan kehadiran pengajaran (teaching presence).

\section{HASIL DAN PEMBAHASAN}

Berdasarkan hasil identifikasi pada pengembangan perangkat pembelajaran mahasiswa calon guru bahasa Indonesia yang telah dikembangkan pada praktik pembelajaran dalam kegiatan Pengenalan Lingkungan Persekolahan (PLP) 2 yang diadakan oleh FKIP Universitas Muhammadiyah Surakarta, berikut akan disajikan hasil dan pembahasan mengenai integrasi kompetensi kecakapan 480 
abad 21 pada pengembangan perangkat pembelajaran tersebut yang akan dihubungkan dengan konsep Community of Inquiry.

\section{Berpikir Kritis (Critical Thinking)}

Berpikir kritis didefinisikan sebagai kemampuan yang harus dimiliki oleh peserta didik sebagai pembelajar yang bertujuan untuk dapat membuat peserta didik tersebut mampu berpikir kritis dengan mengkorelasikan pembelajaran terhadap masalah-masalah secara kontekstual yang terdapat dalam realitas kehidupan sehari-hari (Zulkarnain et al., 2020). Kaitannya dengan pengembangan perangkat pembelajaran, maka keterampilan atau kemampuan berpikir kritis perlu diterapkan oleh guru dalam mempersiapkan atau menyusun serta mengembangkan perangkat pembelajaran agar nantinya peserta didik memiliki kemampuan dalam berpikir secara kritis tersebut. Berikut merupakan wujud atau bentuk integrasi kemampuan berpikir kritis yang terdapat pada pengembangan perangkat pembelajaran.

1.1. Peserta didik diminta membuat satu buah pertanyaan terkait materi pada Kartu Sastra mengenai unsur pembangun puisi yang terdiri dari struktur fisik dan struktur batin.

Data 1.1 di atas merupakan salah satu bentuk integrasi dari keterampilan berpikir kritis (Critical Thinking). Pada data 1.1 tersebut menjadi salah satu wujud integrasi kecakapan abad 21 yang terdapat pada langkah pembelajaran di dalam RPP. Wujud integrasi keterampilan berpikir kritis terlihat dari perintah atau langkah-langkah yang disusun yaitu untuk menciptakan atau menyusun pertanyaan yang berhubungan dengan materi ajar yang telah disampaikan oleh guru, yaitu mengenai unsur pembangun puisi.

Data 1.1 tersebut menjadi wujud dari berpikir kritis karena adanya proses atau kegiatan untuk menghasilkan satu buah pertanyaan yang diminta dari materi yang telah dipahami guru. Hal tersebut berkebalikan seperti biasanya, yang pada umumnya peserta didik diminta untuk menjawab pertanyaan namun kali ini diminta untuk menciptakan atau membuat pertanyaan. Pengintegrasian aspek berpikir kritis sesuai dengan data 1.1 tersebut akan mengedepankan aspek nalar kritis peserta didik dalam menyusun suatu pertanyaan berdasarkan materi yang diajarkan oleh guru. Hal tersebut dapat dipahami bahwa kemampuan berpikir kritis di dalamnya menerapkan berbagai materi yang telah peserta didik pahami dalam proses belajar mengajar yang kemudian disesuaikan dengan permasalahan yang dihadapi dalam proses tersebut. Langkah pembelajaran yang diminta guru bahwa peserta didik diminta untuk menyusun pertanyaan tentunya berdasarkan materi yang telah mereka pelajari yang kemudian dihadapkan dengan suatu permasalahan yang berupa tugas untuk membuat pertanyaan berdasarkan materi tersebut. 
1.2. Tulislah hasil identifikasi kalian mengenai unsur pembangun puisi yang berupa struktur fisik dan struktur batin puisi tersebut pada kotak di bawah ini!

Data 1.2 di atas merupakan salah satu wujud integrasi dari kompetensi kecakapan abad 21 yang berupa kemampuan berpikir kritis. Wujud kemampuan berpikir kritis tersebut ditemukan pada Lembar Kerja Peserta Didik (LKPD). Data 1.2 di atas menjadi salah satu wujud berpikir kritis yang terdapat pada LKPD yang isinya berupa kalimat permintaan atau perintah dari guru untuk peserta didik agar menuliskan hasil identifikasi yang telah dilakukan oleh peserta didik terhadap puisi yang telah disediakan oleh guru dalam LKPD tersebut. Kemampuan berpikir kritis tersebut dalam pengembangan perangkat pembelajaran, tentunya terdapat berbagai indikator yang menjadi tolok ukur dalam mencapai target untuk bisa dikatakan bahwa peserta didik telah mencapai taraf mampu berpikir secara kritis, indikatornya antara lain peserta didik mampu mengidentifikasi, menganalisis atau bisa juga memecahkan masalah yang dihadapinya dalam proses pembelajaran yang dilakukannya dengan kreatif serta logis sehingga mampu menghasilkan keputusan atau capaian yang maksimal.

1.3. Peserta didik mampu mengidentifikasi semua aspek, yaitu diksi, majas, citraan, kata konkret, rima, tipografi, tema, nada dan suasana, perasaan dan amanat pada teks puisi yang disediakan.

Data 1.3 di atas merupakan wujud integrasi dari aspek kemampuan bernalar kritis yang terdapat pada kriteria penilaian dalam instrumen evaluai atau penilaian. Data tersebut menjadi salah satu wuud integrasi dari keterampilan berpikir kritis dilihat dari makna data 1.3 tersebut bahwa untuk mendapatkan skor atau nilai tertentu, peserta didik diharuskan mampu mengidentifikasi semua aspek dalam unsur puisi yang terdiri atas diksi, majas, citraan atau imaji, kata konkret, rima, tipografi atau tata wajah, tema, nada serta suasana, perasaan dan amanat. Dengan tuntutan yang diminta oleh guru yang dituangkan dalam kriteria penilaian tersebut, kaitannya dengan aspek kemampuan bernalar kritis yaitu kegiatan yang dilakukan peserta didik yang berupa identifikasi unsur dalam teks puisi. Kegiatan mengidentifikasi menjadi salah satu wujud kemampuan bernalar kritis karena dalam kegiatan tersebut, nalar peserta didik akan terasah ketika mengidentifikasi berbagai aspek dalam unsur puisi tersebut.

Kaitannya dengan konsep Community of Inquiry, mengenai keterampilan berpikir kritis dalam kompetensi kecakapan abad 21, apabila dihubungkan dengan aspek dalam konsep Community of Inquiry, wujud integrasi keterampilan berpikir kritis tersebut dapat direlevansikan dengan aspek cognitive presence atau kehadiran kognitif dalam konsep Community of Inquiry (CoI). Pada temuan data 1.1, 1.2, dan 1.3 di atas menjadi wujud dari integrasi aspek keterampilan berpikir kritis dalam kompetensi kecakapan abad 21 yang menjadi bagian dari aspek kehadiran kognitif (Cognitive Presence). Hal tersebut selaras dengan indikator yang terdapat dalam kehadiran kognitif (Cognitive 
Presence) pada konsep CoI dalam pembelajaran, bahwa indikator dalam aspek kognitif tersebut antara lain dapat direpresentasikan melalui beberapa kegiatan, yaitu 1) diskusi aktif antarpeserta didik dalam proses pembelajaran, 2) melatih kemampuan dalam berpikir, dan 3) pengembangan aspek keterampilan peserta didik dalam pembelajaran.

\section{Kreativitas (Creativity)}

Kreativitas merupakan suatu kegiatan atau proses untuk menghasilkan sesuatu yang belum pernah ada sebelumnya yang berasal dari elemen atau bagian yang ada namun dengan menyusunnya kembali. Munandar menyatakan bahwa ciri-ciri dari keterampilan berpikir kreatif yaitu berkaitan dengan berpikir secara jelas atau rinci, keaslian serta keluwesan (Wijaya, 2020). Berikut merupakan wujud integrasi keterampilan abad 21 pada aspek kreativitas yang terdapat pada perangkat pembelajaran.

1.4. Peserta didik mempresentasikan hasil indentifikasi mengenai unsur pembangun dalam puisi.

Data 1.4 tersebut merupakan salah satu wujud keterampilan berpikir kreatif. Data tersebut merupakan wujud integrasi keterampilan abad 21 yang terdapat pada langkah pembelajaran yang ada pada RPP. Data 1.4 tersebut berisi mengenai perintah atau langkah dalam pembelajaran yang meminta peserta didik untuk mempresentasikan hasil dari identifikasinya mengenai unsur pembangun puisi yang terdapat dalam puisi yang telah disediakan oleh guru. Hal tersebut tergolong dalam berpikir kreatif didasarkan pada proses presentasi yang dilakukan oleh peserta didik. Ketika melakukan sebuah presentasi di depan orang, tentunya kreativitas sang presenter sangat dibutuhkan. Dalam hal ini bisa dikatakan keluwesan dalam presentasi menjadi salah satu hal penting. Keluwesan dalam hal ini bermakna bahwa presenter dalam mempresentasikan materi atau hasil karyanya mampu mentransfer makna dari sesuatu yang dipresentasikan tersebut kepada pendengar. Dengan kata lain bahwa keluwesan jika dikaitkan dengan presentasi, peserta didik sebisa mungkin memiliki suatu cara yang kreatif sehingga sesuatu yang dipresentasikan tersebut mampu tersalurkan kepada pendengar dengan baik.

1.5. Peserta didik diminta menyusun sebuah teks puisi dengan memerhatikan struktur fisik dan struktur batin puisi.

Data 1.5 tersebut merupakan bentuk dari aspek kreativitas dalam kecakapan abad 21. Data tersebut ditemukan dalam langkah pembelajaran yang terdapat pada RPP. Terlihat pada data tersebut merupakan perintah dari guru yang meminta peserta didik untuk menyusun sebuah puisi dengan memperhatikan unsur pembangun puisi yang terdapat dua aspek, yaitu struktur fisik dan struktur batin, yang nantinya menghasilkan sebuah teks puisi. Kegiatan tersebut tentunya memerlukan 
kreativitas dari peserta didik. Tingkat kreativitas peserta didik tentunya sangat mempengaruhi hasil karya puisinya. Keterampilan kreativitas dalam kompetensi kecakapan abad 21 tersebut tentunya ada sebuah ide yang menjadi dasar dari proses kreatif tersebut yang kemudian menghasilkan sesuatu yang berasal dari ide tersebut. Apabila dihubungkan dengan data 1.5 tersebut maka adanya suatu ide yaitu berkaitan dengan ide peserta didik mengenai puisi yang akan diciptakan, sedangkan mengenai hasil atau produk yaitu berkaitan dengan teks puisi yang dihasilkan oleh peserta didik.

Aspek kreativitas dalam keterampilan abad 21 seperti terlihat pada data 1.4 dan 1.5 , hal tersebut jika direlevansikan dengan konsep CoI (Community of Inquiry) dalam pembelajaran, adanya unsur atau aspek kreatif dari peserta didik untuk menciptakan suatu hal dalam proses pembelajaran tersebut. Hal tersebut tergolong dalam aspek kehadiran pengajaran atau teaching presence dalam konsep CoI (Community of Inquiry).

Kehadiran pengajaran dalam konsep CoI (Community of Inquiry) tersebut, salah satu indikator dari aspek tersebut yaitu adanya satu poin penekanan dalam mengintegrasikan berbagai macam ide dari peserta didik yang berhubungan dengan materi yang disampaikan dalam proses belajar mengajar tersebut. Hal tersebut menjadi sebuah kegiatan yang menuntut kreativitas peserta didik mengenai materi pembelajaran dengan menuangkan atau menggali ide-ide kreatif mereka dalam proses pembelajaran.

\section{Komunikasi (Communication)}

Keterampilan komunikasi merupakan beberapa orang yang secara tatap muka atau bertemu secara secara langsung, yang kemungkinkan setiap orang nya menangkap reaksi orang lain (Faricha et al., 2021). Berikut merupakan wujud integrasi keterampilan abad 21 pada aspek komunikasi yang terdapat pada perangkat pembelajaran.

1.6. Peserta didik membacakan hasil karya puisinya di depan guru dan teman teman.

Data 1.6 tersebut merupakan bentuk integrasi keterampilan abad 21 pada aspek komunikasi yang terdapat pada langkah-langkah pembelajaran pada RPP. Langkah pembelajaran tersebut menjadi salah satu bentuk integrasi aspek komunikasi terlihat dari aktivitas yang ada yaitu berupa pembacaan hasil karya puisi peserta didik di depan kelas. Dalam membacakan teks puisi tersebut tentunya ada aspek komunikasi di dalamnya. Membacakan puisi pada data 1.6 tersebut menjadi salah satu aktivitas atau kegiatan dalam menyampaikan atau mempresentasikan informasi yang berupa hasil karya peserta didik yang berupa teks puisi. Pembacaan teks puisi tersebut menjadi wujud dari integrasi kreativitas atau kemampuan komunikasi peserta didik dilihat dari hal-hal yang menjadi dasar 
dalam kemampuan berkomunikasi pada kompetensi kecakapan abad 21 yaitu mengungkapkan suatu informasi serta pendapat di depan orang.

1.7. Guru memberikan pertanyaan-pertanyaan seputar cara menulis teks puisi kemudian peserta didik mengutarakan ide-ide terkait pertanyaan yang disampaikan oleh guru.

Data 1.7 di atas merupakan bentuk integrasi aspek komunikasi yang terdapat pada langkahlangkah pembelajaran dalam RPP. Data tersebut menjadi salah satu wujud dari aspek komunikasi dalam pembelajaran berdasar pada adanya hubungan interaktif antara peserta didik dengan guru dalam pembelajaran. Pada data tersebut proses komunikasi terwujud pada aktivitas guru dalam memberikan berbagai pertanyaan kepada peserta didik mengenai materi cara menulis teks puisi kemudian peserta didik sebagai mitra dalam proses komunikasi tersebut memberikan ide-idenya atau jawaban terkait dengan pertanyaan yang diberikan oleh guru tersebut.

1.8. Peserta didik terampil dalam menyusun pertanyaan, menjawab pertanyaan dari teman, terampil dalam berbicara, dan lancaran dalam mengungkapkan jawaban selama diskusi.

Data 1.8 di atas merupakan wujud integrasi dari aspek kemampuan komunikasi yang terdapat pada kriteria penilaian dalam instrumen evaluai atau penilaian. Data tersebut menjadi salah satu wuud integrasi dari keterampilan berpikir kritis dilihat dari makna data 1.8 tersebut bahwa untuk mendapatkan skor atau nilai tertentu, peserta didik diharuskan mampu menyusun pertanyaan, menjawab pertanyaan dari teman, terampil dalam berbicara, dan lancara dalam mengungkapkan jawaban selama diskusi. Berdasarkan aspek-aspek tersebut, menjadi penanda bahwa hal tersebut merupakan aspek yang membutuhkan kemampuan peserta didik dalam berkomunikasi. Kemampuan komunikasi kaitannya dengan kompetensi kecakapan abad 21 berdasarkan data 1.8 tersebut secara eksplisit telah disusun oleh guru dalam kriteria penialain yang terdapat pada instrument penilaian atau evaluasi yang merupakan bagian dari penilaian keterampilan peserta didik dalam pembelajaran.

Pada praktiknya, integrasi dari kemampuan komunikasi peserta didik sering dihubungkan dengan kemampuan berkolaborasi yang bertujuan untuk menciptakan suatu keberhasilan serta keefektifan dalam proses pembelajaran. Berdasarkan hal tersebut, apabila dikaitkan dengan data 1.8 di atas, bahwa dalam proses pembelajaran tersebut terdapat aspek komunikasi dan juga kolaborasi. Aspek komunikasi ditunjukkan dengan adanya interaksi secara lisan antara peserta didik dan guru, kemudian mengenai aspek kolaborasi terlihat pada adanya peran dari masing-masing pelaku dalam pembelajaran yaitu guru dan peserta didik mengenai tugas atau posisinya dalam pembelajaran yaitu Ketika guru memberikan pertanyaan kemudian peserta didik memberikan ide atau jawaban dari pertanyaan tersebut. Sehingga kemampuan kolaborasi mampu tercipta dengan baik dalam proses pembelajaran. 


\section{Kolaborasi (Collaboration)}

Kolaborasi merupakan kemampuan yang bermanfaat bagi peserta didik agar mampu menciptakan hubungan dengan orang lain serta bertanggung jawab untuk dirinya sendiri maupun untuk orang lain (Sholikha \& Fitrayati, 2021). Berikut merupakan wujud integrasi keterampilan abad 21 pada aspek kolaborasi yang terdapat pada perangkat pembelajaran.

1.9. Peserta didik menanyakan mengenai unsur pembangun teks puisi (struktur fisik dan struktur batin) kepada guru.

Data 1.9 di atas merupakan bentuk integrasi aspek kolaborasi yang terdapat pada langkahlangkah pembelajaran dalam RPP. Pada data tersebut di dalamnya mengandung makna bahwa adanya timbal balik antara guru dan peserat didik. Peserta didik bersama guru melakukan adanya proses kolaborasi yang ada dalam konteks tanya jawab. Peserta didik menanyakan materi mengenai unsur pembangun puisi kemudian guru memberikan penjelasan mengenai materi tersebut.

Kegiatan atau aspek kolaborasi pada data tersebut dilihat dari adanya kegiatan saling memberi dan menerima informasi dalam proses pembelajaran. Kegiatan tersebut tentunya dilakukan oleh peserta didik dengan guru melalui proses komunikasi. Oleh karena itu, kemampuan berkolaborasi dalam proses pembelajaran tentu tidak dapat dipisahkan satu sama lain. Adanya kolaborasi menuntut juga adanya interaksi satu sama lain. Terciptanya sebuah interaksi tersebut tentunya memerlukan keterampilan seseorang dalam berkomunikasi secara efektif dan efisien. Aspek kolaborasi menjadi aspek yang di dalamnya terdapat kegiatan menerima serta memberi umpan balik atau feedback dari seseorang berkaitan dengan suatu topik tertentu.

1.10. Peserta didik bersama guru menyimpulkan pembelajaran mengenai materi suasana, tema, dan makna dari beberapa puisi dalam buku antologi puisi.

Data 1.10 tersebut merupakan wujud dari aspek kolaborasi yang ditemukan pada langkah pembelajaran dalam RPP. Bentuk kolaborasi pada data tersebut terlihat ketika adanya suatu aktivitas atau kegiatan yang sama-sama dilakukan oleh peserta didik dan guru. Keterampilan berkolaborasi ini memiliki manfaat bagi guru maupun peserta didik, dalam hal ini guru, kaitannya dengan kemampuan dalam bekerja sama serta memiliki rasa tanggung jawab atas sesuatu yang dilakukannya tersebut. Aspek berkolaborasi pada data 1.10 tersebut menjadi salah satu bentuk integrasi kecakapan abad 21 yang terdapat dalam langkah-langkah pembelajaran. Peserta didik sebagai objek dalam pembelajaran mampu menumbuhkan sikap atau keterampilan berkolaborasi dengan guru pada proses pembelajaran.

Relevansinya dengan konsep Community of Inquiry (CoI), mengenai aspek komunikasi dan kolaborasi dalam kompetensi kecakapan abad 21, pada praktiknya dua aspek tersebut dapat dilakukan 
secara bersama-sama atau beriringan. Dengan kata lain bahwa kegiatan yang berkaitan dengan kolaborasi tentu di dalamnya terdapat aspek atau kegiatan berkomunikasi satu sama lain mengenai topik yang dibicarakan atau bisa dikatakan bahwa aspek komunikasi dan kolaborasi menjadi satu kesatuan yang berjalan secara bersamaan dalam proses pembelajaran.

Kaitannya dengan konsep pembelajaran Community of Inquiry (CoI), aspek komunikasi dan kolaborasi seperti yang terdapat pada temuan data 1.6, 1.7, 1.8, 1.9, dan 1.10, konsep Community of Inquiry (CoI) yang selaras dengan aspek komunikasi dan kolaborasi tersebut yaitu berkaitan dengan aspek kehadiran sosial atau social presence. Selaras dengan indikator dalam aspek kehadiran sosial bahwa kehadiran sosial mengacu pada kemapuan untuk memahami pembelajaran dengan melibatkan komunikasi terbuka, serta kohesi kelompok. Hal tersebut sesuai dengan temuan data 1.6 sampai 1.10 bahwa adanya komunikasi antar peserta didik yang secara eksplisit memunculkan adanya suatu kolaborasi dalam sebuah proses pembelajaran yang di dalam prose tersebut tentu terdapat komunikasi secara terbuka dan juga adanya hubungan atau interaksi antarkelompok dalam mewujudkan kompetensi kecakapan abad 21 yang berupa kemampuan komunikasi dan kolaborasi.

\section{KESIMPULAN}

Berdasarkan hasil dan pembahasan yang telah disampaikan, dapat ditarik simpulan bahwa integrasi kecakapan abad 21 dalam pengembangan perangkat pembelajaran dalam konsep Community of Inquiry terdapat empat aspek secara keseluruhan, yaitu Critical thinking, Creativity, Communication, dan Collaboration atau dikenal dengan istilah 4C. Berdasarkan temuan tersebut integrasi mengenai empat aspek dalam kecakapan abad 21 tersebar pada beberapa jenis perangkat pembelajaran, yaitu Rencana Pelaksanaan Pembelajaran (RPP) yang terdapat pada langkah-langkah pembelajaran, Lembar Kerja Peserta Didik (LKPD) dan instrument penilaian. Mengenai aspek Community of Inquiry yang direlevansikan dengan kecakapan abad 21 dalam perangkat pembelajaran, ditemukan aspek kehadiran sosial (social presence), kehadiran kognitif (cognitive presence), dan kehadiran pengajaran (teaching presence). Berdasarkan ketiga aspek tersebut, aspekaspek kecakapan abad 21, meliputi aspek berpikir kritis terintegrasi dalam aspek kehadiran kognitif (cognitive presence), aspek kreativitas terintegrasi dalam aspek kehadiran sosial (social presence), dan aspek komunikasi serta kolaborasi terintegrasi dalam aspek kehadiran pengajaran (teaching presence). Saran untuk penelitian selanjutnya, mengenai kompetensi kecakapan abad 21 menekankan pada aspek pembelajaran. Jika dalam penelitian ini perangkat pembelajaran yang dijadikan sebagai objek, maka untuk penelitian selanjutnya proses pembelajaran digunakan sebagai objek untuk memperluas cakupan yang ada dalam penelitian. 


\section{DAFTAR PUSTAKA}

Anggraeni, P., \& Akbar, A. (2018). Kesesuaian Rencana Pelaksanaan Pembelajaran dan Proses Pembelajaran. Jurnal Pesona Dasar, 6(2), 55-65. https://doi.org/10.24815/pear.v6i2.12197

Faricha, I. F. E., Praherdhiono, H., \& Adi, E. P. (2021). Studi Keterampilan Abad 21 Mahasiswa dalam Memilih Peminatan. Jurnal Kajian Teknologi Pendidikan, 4(3), 251-259. https://doi.org/10.17977/um038v4i32021p251

Fitri, M., Yuanita, P., \& Maimunah. (2020). Pengembangan Perangkat Pembelajaran Matematika Terintegrasi Keterampilan Abad 21 Melalui Penerapan Model Problem Based Learning (PBL). Jurnal Gantang, 5(1), 77-85.

Hamidah, N., Haryani, S., \& Wardani, S. (2018). Efektivitas Lembar Kerja Peserta Didik Berbasis Inkuiri Terbimbing untuk Meningkatkan Hasil Belajar Siswa. Jurnal Inovasi Pendidikan Kimia, 12(2), 2212-2223.

Kirana, N. C., Anggraeni, S., \& Diana, S. (2021). Pengaruh Penerapan Community of Inquiry Menggunakan LINE terhadap Keterampilan Berpikir Kreatif Siswa SMA pada Materi Energi Terbarukan. Assimilation: Indonesian Journal of Biology Education, 4(1), 24-31. https://doi.org/10.17509/aijbe.v4i1.34822

Kurniawan, B. (2020). Implementasi Pendidikan Tekhnohumanistik Berbasis 4C dalam Membentuk Karakter Peserta Didik. Indonesian Values and Character Education Journal, 3(1), 40-46. https://ejournal.undiksha.ac.id/index.php/IVCEJ/article/view/27219

Letasado, M. R., \& Muhsam, J. (2020). Pengaruh Implementasi Pembelajaran Saintifik Berbasis Keterampilan Belajar dan Berinovasi 4C terhadap Percaya Diri dan Kemampuan Membaca Pemahaman. Musamus Journal of Primary Education, 2(2), 76-84. https://doi.org/10.35724/musjpe.v2i2.2559

Marsudi, S., Darsinah, Rubiyanto, R., \& Surtikanti. (2019). Bimbingan dan Konseling di Sekolah. Fakultas Keguruan dan Ilmu Pendidikan UMS.

Nurhaifa, I., Hamdu, G., \& Suryana, Y. (2020). Rubrik Penilaian Kinerja pada Pembelajaran STEM Berbasis Keterampilan 4C. Indonesian Journal of Primary Education, 4(1), 101-110. https://ejournal.upi.edu/index.php/IJPE/article/view/24742

Partono, Wardhani, H. N., Setyowati, N. I., Tsalitsa, A., \& Putri, S. N. (2021). Strategi Meningkatkan Kompetensi 4C (Critical Thinking, Creativity, Communication, \& Collaborative). Jurnal Penelitian Ilmu Pendidikan, 14(1), 41-52. https://doi.org/10.21831/jpipfip.v14i1.35810 
Putri, R. R., Asrizal, Desnita, \& Sari, S. Y. (2019). Efek LKS IPA Bermuatan Keterampilan Belajar 4C Tema Kesehatan Pernapasan dan Ekspresi Kita pada Hasil Belajar Siswa Kelas VIII SMPN 7 Padang. Pillar of Physics Education, 12(3), 377-384. http://ejournal.unp.ac.id/students/index.php/pfis/article/view/6568

Rafi, I., Sabrina, N., \& Latifah, R. A. (2016). Penerapan Metode Pembelajaran Bamboo Dancing dalam Pembelajaran Keliling dan Luas Segiempat dan Segitiga untuk Meningkatkan Keterampilan 4C Siswa SMP Kelas VII. Seminar Nasional Pendidikan Matematika Ahmad Dahlan, 2, 99-104.

Septikasari, R., \& Frasandy, R. N. (2018). Keterampilan 4C Abad 21 dalam Pembelajaran Pendidikan Dasar. Jurnal Tarbiyah Al-Awlad, 8(2), 112-122. https://doi.org/10.1016/j.jacc.2020.04.015

Setiaji, H., Winarno, W. W., \& Kusumawardani, S. S. (2015). Pengembangan Faktor Learner Satisfaction Dengan Menggunakan Kerangka Kerja Community of Inquiry. Seminar Nasional Teknologi Informasi dan Komunikas, 324-332.

Setiawan, R., \& Komalasari, E. (2020). Membangun Efektifitas Pembelajaran Sosiologi di Tengah Pandemi Covid-19. Edusocius: Jurnal Ilmiah Penelitian Pendidikan dan Sosiologi, 4(1), 1-13. https://ejournal.undiksha.ac.id/index.php/ED/article/viewFile/25073/15152

Sholikha, S. N., \& Fitrayati, D. (2021). Integrasi Keterampilan 4C dalam Buku Teks Ekonomi SMA/MA. Edukatif: Jurnal Ilmu Pendidikan, 3(5), 2402-2418.

Simanjuntak, M., Bukit, N., Sagala, Y. D. A., Khairani putri, R., Utami, laksmitha zaskya, \& Motlan. (2019). Desain Pembelajaran Berbasis Proyek Terhadap 4C. Jurnal Inovasi Pembelajaran Fisika (INPAFI), 7(3), 38-46.

Soleh, A. R., Purnomo, E., \& Pratiwi, D. R. (2021). Analisis Kesesuaian Isi Bahan Ajar Daring dan Kurikulum di Website Kemendikbud sebagai Penunjang Pembelajaran Jarak Jauh. Urecol Journal. Part A: Education and Training, 1(1), 18-24. https://doi.org/https://doi.org/10.53017/ujet.21

Sugiyarti, L., Arif, A., \& Mursalin. (2018). Pembelajaran Abad 21 di SD. Prosiding Seminar dan Diskusi Nasional Pendidikan Dasar, 439-444.

Sugiyono. (2015). Metode Penelitian Pendidikan: Pendekatan Kuantitatif, Kualitatif, dan R\&D. Alfabeta. 
Susanti, E., \& Arista, A. (2019). Analisa Tingkat Pengetahuan Guru terhadap Kompetensi 4C. Prosiding Seminar Nasional Ilmu Sosial dan Teknologi (SNISTEK), September, 73-78. http://ejournal.upbatam.ac.id/index.php/prosiding/article/view/1509

Wijaya, I. K. B. (2020). Pengembangan Kompetensi 4C dan Keterampilan Proses Sains melalui Pembelajaran Berbasis Catur Pramana. Guna Widya: Jurnal Pendidikan Hindu, 7(1), 70-76.

Yusliani, E., Burhan, H. L., \& Nafsih, N. Z. (2019). Analisis Integrasi Keterampilan Abad Ke-21 dalam Sajian Buku Teks Fisika SMA Kelas XII Semester 1. Jurnal Eksakta Pendidikan, 3(3), 184-191.

Zendrato, J. (2016). Tingkat Penerapan Rencana Pelaksanaan Pembelajaran dalam Pelaksanaan Pembelajaran di Kelas: Suatu Studi Kasus di SMA Dian Harapan Jakarta. Scholaria : Jurnal Pendidikan dan Kebudayaan, 6(2), 58-73. https://doi.org/10.24246/j.scholaria.2016.v6.i2.p5873

Zulkarnain, I., Suryaningsih, Y., Noorbaiti, R., \& Rahadian, L. N. N. R. (2020). Bimbingan Penyusunan Perangkat Pembelajaran 4C (Communication, Collaboration, Critical Thinking, and Creativity) bagi Guru Peserta MGMP Matematika SMA Kota Banjarmasin. Bubungan Tinggi: Jurnal Pengabdian Masyarakat, 2(1), 37-44. https://doi.org/10.20527/btjpm.v2i1.1804 